Review

\title{
Biochars and Their Use as Transesterification Catalysts for Biodiesel Production: A Short Review
}

\author{
John Vakros \\ Department of Chemistry, University of Patras, GR 26504 Patras, Greece; vakros@chemistry.upatras.gr; \\ Tel.: +30-26-1099-7143
}

Received: 16 October 2018; Accepted: 14 November 2018; Published: 20 November 2018

\begin{abstract}
Biodiesel can be a significant alternative for diesel. Usually, it is produced through transesterification with a base catalyst. Using heterogeneous catalysts for transesterification, the process can be more efficient. Among the possible catalysts that can be used, biochars combine high performance for transesterification and valorization of waste biomass. Biochars are cheap materials, and are easy to activate through chemical treatment with acid or base solutions. In this short review, the application of biochar as solid heterogeneous catalysts for transesterification of lipids to produce biodiesel is discussed.
\end{abstract}

Keywords: biodiesel; biochar; acid modification; base modification; transesterification; pseudocatalytic transesterification

\section{Introduction}

Two great challenges that people are called to face in our time is to meet the increasing demand for energy and to reduce the wastes released in the environment. The energy challenge is approached with $\mathrm{CO}_{2}$ neutral fuels like biofuels. Among them, biodiesel has significant advantages and it is preferable for using in existing engines and transport infrastructures. Biodiesel is usually produced through transesterification/esterification of lipids [1]. This process requires the presence of a catalyst.

On the other hand, biomass is a class of solid wastes with interesting properties. Biomass can be used directly as fuel, or through gasification or pyrolysis, and produce valuable products. What is more attractive is that the by-product of the pyrolysis process is a carbon rich solid called biochar. Biochars have unique properties and can have significant applications in environmental protection [2].

In this short review, the potential use of biochars as heterogeneous catalysts for transesterification/esterification reaction for producing biodiesel will be discussed.

\section{Biodiesel}

Diesel is a liquid fuel containing $\mathrm{C}_{8}-\mathrm{C}_{25}$ hydrocarbons and is produced from petroleum by fractional distillation at temperatures $200-350{ }^{\circ} \mathrm{C}$. It is used in diesel engines for transportation and heating. Gasoline and diesel cannot be used in the same engine, so renewable fuel sources to diesel are required for partial substitution of diesel. The two main alternatives are biodiesel and green diesel $[3,4]$.

Biodiesel and green diesel are both produced from triglycerides but biodiesel has a significant amount of oxygen while green diesel consists of hydrocarbons. The green diesel is produced through selective deoxygenation under high pressure of hydrogen (10-80 bar) and moderate temperatures $\left(260-360^{\circ} \mathrm{C}\right)$, and requires catalysts with hydrogenation ability like Ni or precious metals [5-7].

Biodiesel is a renewable liquid fuel and a potential alternative to diesel. It is a yellowish liquid derived from lipids through transesterification reaction with methanol or ethanol in the presence of basic catalysts. The chemical form of biodiesel is methyl esters of fatty acids and has $90 \%$ of the 
energy density of the diesel. Biodiesel is non-toxic, with low or no sulfur and aromatic compounds. The main biodiesel advantages are that it is carbon neutral and it has the same properties with the diesel, which make it easier to replace without engine modification. Biodiesel can be produced from many sources like straight vegetable oil, animal oil/fats or waste cooking oil. The most popular method for biodiesel production is the transesterification process [8].

According to this method, a vegetable oil or a fat feedstock reacts with an alcohol, like methanol or ethanol, in the presence of a catalyst to produce esters. The scheme of the reaction can be seen in Figure 1 . The triglyceride converts to di- and mono-glyceride and finally to fatty esters. The reaction needs the presence of a catalyst and an excess of alcohol. The reaction is a three-step reversible reaction with diglyceride and monoglyceride as intermediate products. Most of the kinetic studies for transesterification reaction consider the reaction as pseudo-homogeneous first order and it was assumed that the methanol and catalyst are sufficient for the reaction to shift the reaction equilibrium towards the formation of products and that the reverse reaction is negligible. Also, with a high excess of methanol, the change in concentration of methanol in the reaction would be negligible [9].
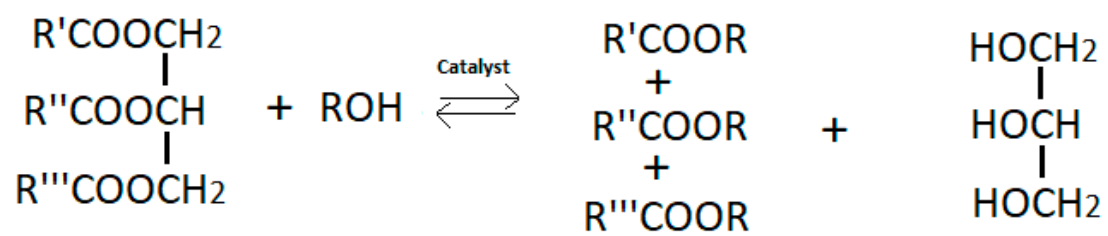

Figure 1. Transesterification reaction scheme.

In most cases, the catalyst is a strong base like $\mathrm{NaOH}$ or $\mathrm{KOH}$ [10]. The strong base is dissolved in methanol and the catalyst is working homogenous. The reaction takes place in the interface between the alcoholic solution and the oil and needs intense stirring. This is the most economical process because it requires a lower ratio between oil and methanol (usually 1:6) and low temperatures and atmospheric pressures, producing 98\% conversion yield in relative low reaction times (between 1 to $3 \mathrm{~h}$ ). The amount of the catalyst used is $1 \% w / w$. When the reaction completes, the glycerol and the excess of methanol have to be removed. Gravity separation is used for the removal of glycerol and this requires about $4-8 \mathrm{~h}$. The upper layer contains biodiesel while the second layer contains glycerol, about $90 \%$ of the base catalyst and $70 \%$ of the excess methanol. The biodiesel layer also contains some contaminants, like methanol, free glycerol, and residual catalyst. These contaminants are water soluble and can be removed through hot water washing. This step is the most problematic step, because water has to be removed completely from biodiesel and also neutralized before disposal. The process is complicated and the following parameters can influence the yield of the transesterification/esterification reaction [11].

Catalyst amount: An excess of catalyst amount is required for shorter reaction times and also to prevent the reversible reaction. For homogeneous catalysis, an amount of $\% \mathrm{wt} / \mathrm{wt}$ is the optimum. A higher amount of catalysts increase the cost and makes separation between the catalyst, methanol and biodiesel more difficult.

Reaction temperature: The activity of the catalyst depends on the reaction temperature. Higher reaction temperatures increase the reaction rate. In homogeneous catalysis, the temperature should not be exceeded the boiling point of the mixture, about $65^{\circ} \mathrm{C}$ for methanol use.

Alcohol to oil ratio: Usually methanol is employed in the transesterification reaction, because it requires lower temperatures and reaction times for the treatment. The molar ratio for transesterification of triglycerides is 1:3 according to the reaction scheme. A higher amount of methanol helps to achieve lower reaction times and higher conversion. The ratio 1:6 is the optimum ratio.

Reaction time: Reaction time between 1 and $3 \mathrm{~h}$ is usually enough for achieving conversion higher than $98 \%$.

Stirring: The transesterification reaction takes place in the interface between the lipids and the methanol. In the absence of the stirring condition, the conversion is low and vigorous stirring is needed 
to diminish the mass transfer limitations. During the reaction and the increment of ester concentration in the mixture, the interfacial region is increased, resulting in a more homogeneous mixture, with lower mass transfer limitations.

When the feedstock has a significant amount of free fatty acids, as in the case of waste cooking oils or lipids from microalgae, the basic catalyst is not working properly and the main reaction is the esterification of the fatty acids [12]. The high acidity of the oil neutralizes the base catalyst and the esterification reaction is inhibited. Also, if the free fatty acid level or water level is too high it may cause problems with soap formation and the separation of the glycerol by-product. In these cases, an acid catalyst can be used also in the homogenous phase. In spite of the advantages of the homogeneous catalysts, there are some disadvantages also. The catalysts used cannot be reused and it is difficult to separate from biodiesel and glycerol products; the catalysts are corrosive and there is a high cost on the wastewater treatment system to neutralize the catalyst before discharging. Using a heterogeneous catalyst, many of the above problems can be overcome because it is easy to reuse the catalyst, less or no water is produced and the separation of biodiesel and glycerol is easier. This means that by using heterogeneous catalysts the cost of the biodiesel production could be reduced. One other advantage is that transesterification and esterification can occur simultaneously. On the other hand, the reaction in the presence of a solid catalyst results in the formation of three phases (solid-alcohol-oil) and the mass transfer limitations are more pronounced [13-16].

The solid catalysts for the transesterification reaction can be either basic or acid solids. Some of the commonly used heterogeneous base catalysts are $\mathrm{K}, \mathrm{Na}$, Ca or $\mathrm{Mg}$ oxides supported on $\mathrm{Al}_{2} \mathrm{O}_{3}$, basic zeolites and other basic solids. Using these catalysts requires significant amounts of catalysts to obtain a high yield of biodiesel. Also, there are a number of reported heterogeneous solid acid catalysts such as strong acidic ion exchange resins (e.g., amberlyst), acid zeolites and sulfated zirconia. These catalysts are expensive or have low intrinsic activity.

One interesting approach is the utilization of biomass waste, in the form of biochar, for the production of solid catalysts. This approach will reduce the cost of the catalyst and can also help in the disposal of biomass waste. The possible forms of biomass used for the production of biochars are unlimited. It is very interesting that every country has different distributions of biomass waste. In some cases, the distribution is different even among regions in the same country. On the other hand, all kinds of biomass can be used for biochar production. In the next chapter, the biochar production and the characteristics of the produced biochars will be discussed.

\section{Biochar}

Biochar is produced through pyrolysis or gasification of biomass in the absence of (or very low) oxygen [2]. The higher the oxygen is, the less biochar produced. The optimization of the pyrolysis process requires no oxygen. During heating, the biomass starts loosing water (drying step) and then some bonds dissociate, while partial oxidation and reduction take place. A portion of gas is produced while the remaining solid is enriched with carbon and mineral deposits (ash content). At the beginning, the biochar was considered as a by-product in syngas production, but the properties of biochars made them valuable. Generally, biochar presents high surface area and a significant amount of surface groups (acidic or basic) that can participate in adsorption processes. The biochars can be used as fuels, immobilize heavy metals, pesticides and other organic pollutants, prevent bacteria and nitrates leaching in water, activate persulfates for the oxidation of pollutants, and act as catalysts or catalyst supports [17-21]. In the latter case, the composition of ash should be carefully examined because it may have catalytically active or poisoning species. The dust usually presented in biochars should also be removed before the reaction to prevent contamination or problems with pressure in catalytic reactors. However, there is another problem with dust, as the biochars are extremely gentle and thus highly dusty. During the process, especially under high stirring, small carbon particles could be formed which have to be removed from the biodiesel. 
It is important to note that there are many different sources of biomass that can be used for the production of biochar. The raw materials influence the physicochemical characteristics of the produced biochar. Biomass with different amounts of hemicellulose, cellulose, lignin and mineral deposits may yield biochars with different properties. The calcination temperature determines also the composition of biomass. Rich in lignin biomass demands calcination temperatures higher than $600{ }^{\circ} \mathrm{C}$, while in the absence of lignin, we can obtain the graphitic structure even at low temperatures $\left(350^{\circ} \mathrm{C}\right)$.

The microstructure of the biochar is also affected from the starting biomass. Roots or wood can give biochar with channels. The channels can be seen in Figure 2a where the biochar is formed from spent malt rootlets, which is a waste of the brewing industry.
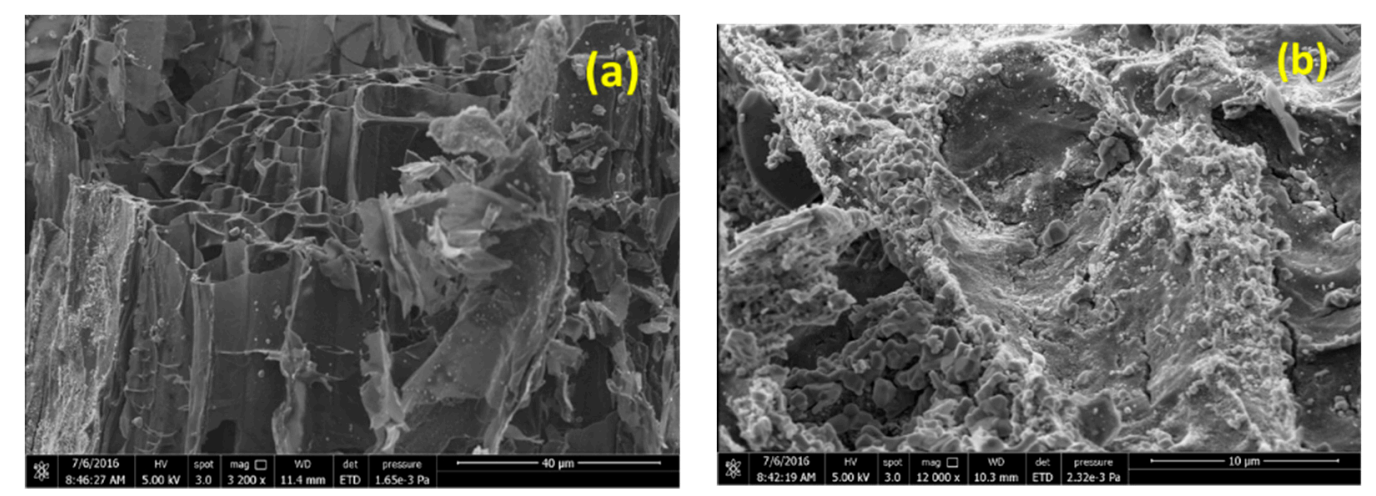

Figure 2. SEM images for a biochar produced from spent malt rootlets at $850{ }^{\circ} \mathrm{C}$. (a) The macropores structure of biochar and $(\mathbf{b})$ the mineral deposits onto its surface.

The inorganic elements in the biomass are also very important. The most usual elements found on biochars are $\mathrm{K}, \mathrm{Na}, \mathrm{Ca}, \mathrm{Mg}, \mathrm{Fe}, \mathrm{P}, \mathrm{Si}$, and $\mathrm{S}$. During calcination and carbon removal, the inorganic elements are enriched and transformed into oxides. The metal oxides are responsible for the basic character of the biochars while the acid sites are closely related with $\mathrm{P}, \mathrm{Si}$ and $\mathrm{S}$ and $\mathrm{CO}$ surface groups. In Figure $2 b$, the mineral deposits onto the biochar surface can be easily seen. Finally, the heating temperature is also a very important parameter. Generally, higher temperatures result in more basic surfaces, as a result of higher ash content [18].

\subsection{Activation of Biochars through Chemical Treatment}

The activation process is performed to produce biochars with increasedly specific surface area pore volume, enlarged pore diameter and enhanced porosity [22,23].

Chemical activation is better than physical activation because it produces biochars with a higher surface area and a higher amount of surface groups. Chemical activation can be performed with impregnation of the starting biochar with an active solution of either acidic or basic, or even an oxidative agent [24].

Generally, the final properties of the activated biochar are dependent on the properties of the biomass precursor and also on the activation method employed [8].

Activation with acids: Treatment with acid solutions like $\mathrm{H}_{2} \mathrm{SO}_{4}$ or $\mathrm{HNO}_{3}$ can alter significantly the surface area of the biochar. The main result of the chemical treatment with an acid solution is an increase in the acidity of the surface. Especially, in the case of $\mathrm{H}_{2} \mathrm{SO}_{4}$, new sulfonic acid groups are formed. The quantity of the acid groups is a function of the concentration of the acid, the temperature of the treatment and the content of hemicellulose, cellulose and lignin in the biochar. These groups are highly acidic and result in a significant Bronsted acidity and lower point of zero charge of the surface. For this point, it must be noted that the surface oxygenated groups of a solid can release or consume $\mathrm{H}^{+}$when the solid is immersed into an electrolyte solution. This process is $\mathrm{pH}$ dependent. Usually, when $\mathrm{pH}$ is high, the surface groups release $\mathrm{H}^{+}$into the solution and they are negatively charged; 
while in low $\mathrm{pH}$ values, the surface is positively charged. There is a $\mathrm{pH}$ in which the surface has zero charge [25].

This is called the point of zero charge, pzc, and depends on the nature of the solid. Treatment with an acid solution lowers the pzc of the biochar as a consistency of the formation of new surface sites. These sites are also carboxyl and/or phenolic groups created during treatment as a result of surface oxidation. Other interesting results of the chemical treatment are a significant increment in surface area and the removal of mineral deposits, especially metal oxides. The latter have a strong base character and they can react with the acid solution and be dissolved. Finally, the acid treatment helps the solubilization of hemicellulose, leaving insoluble the cellulose and the main part of the lignin in the biochar [26]. In Figure 3a, the surface of the acid treated biochar can be seen. The starting biochar presented in Figure 2 was treated with a dilute acid solution $\left(\mathrm{H}_{2} \mathrm{SO}_{4} 0.1 \mathrm{M}\right)$ for 45 min under reflux.
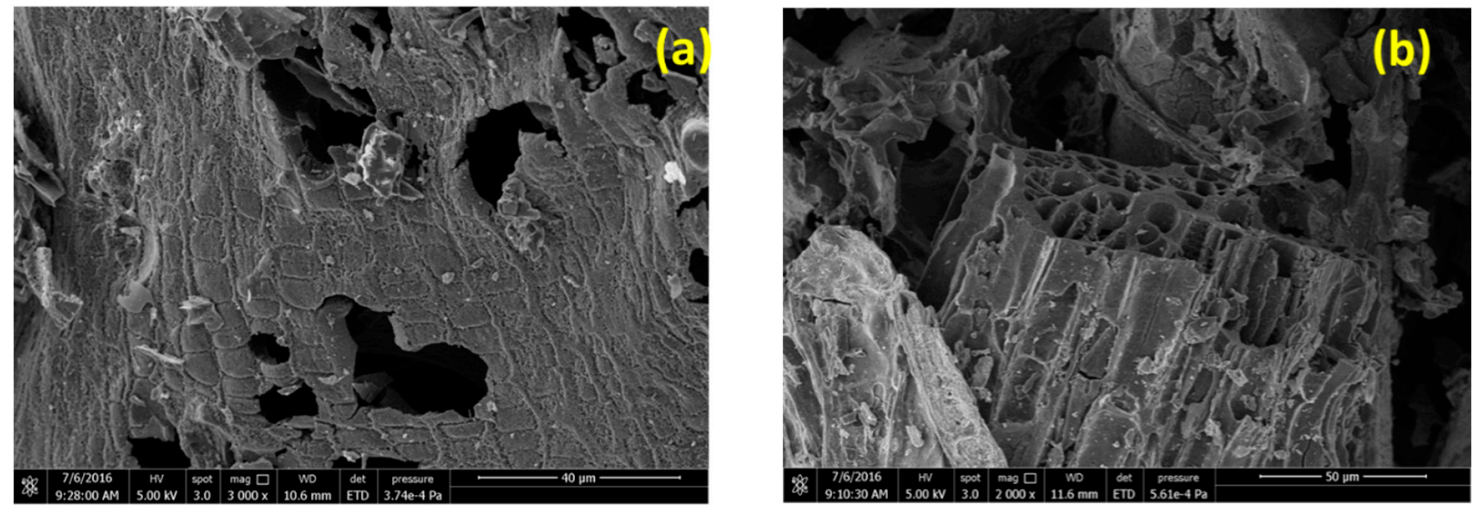

Figure 3. SEM image for the biochar treated with $\mathrm{H}_{2} \mathrm{SO}_{4} 0.1 \mathrm{M}(\mathbf{a})$ and $\mathrm{NaOH} 0.1 \mathrm{M}(\mathbf{b})$.

Activation with bases: Treatment with a base such as $\mathrm{NaOH}$ or $\mathrm{KOH}$ has been commonly adopted to increase the surface area and porosity of biochar [27-29]. Basic solutions have been proven to solubilize lignin, while hemicellulose remains in the cellulosic residue. The treatment with a base solution increases the pzc of the biochar because new basic sites are generated onto the surface. These sites are closely related with the basic oxides of $\mathrm{Na}$ and $\mathrm{K}$ formed during the chemical treatment. On the other hand, a significant amount of the ash content is dissolved and removed from the biochar. This can be clearly seen in Figure $3 \mathrm{~b}$ where the starting biochar has been treated with $\mathrm{NaOH} 0.1 \mathrm{M}$ solution for 45 min under reflux.

\subsection{Biodiesel Formation through Transesterification Reaction Using Different Biochars as Catalysts}

In the last years, there has been a systematic effort from many researchers to work with "green" catalysts. There are many advantages because they are more environmental friendly, cheap and reusable. According to this, biodiesel production through transesterification can be performed using biochars. The experimental processes in the above topic can be derived in three main categories. The majority of the research uses acid catalysts produced from treatment with sulfuric acid of different types of biochars. One other part is the use of basic modified biochars. These are biochars treated with alkali solutions or biochars used as support for basic catalysts like $\mathrm{CaO}$. In this category, one can add the catalysts produced from biomass from animal wastes rich in Ca like shells or bones [30]. The pyrolysis product of this biomass is $\mathrm{CaO}$ or $\mathrm{CaCO}_{3}$ and it will not be analyzed further [31].

Finally, biochar can be used as an inert pore material in which the reaction of transesterification can occur with elevated temperatures. Heating methanol and lipids result in a two phase system. The methanol is in gaseous phase while the lipids are liquids. The reactants fulfilled the pores of the solid catalyst and can react easier with lower activation energy, even if the solid is inert. Silica was the first support tested [32], although biochars can be a promising alternative, due to the high porosity and also the easiness in tuning surface area and porosity. 
One other interesting application of biochars is using them as support for the active phase. This is common for base catalysts, where a basic oxide can be supported but is also valid for immobilization of proper enzymes like lipase onto biochar surface [33].

Biochars usually have microporous and mesoporous structures. The reactants in transesterification are the large triglyceride molecules with an average dimension of $5.8 \mathrm{~nm}$ while the free fatty acid molecules are smaller. The high mesoporosity of the biochars let them access the majority of the surface active sites and react with methanol [34].

One other advantage of biochar is the hydrophobic carbon phase. This hydrophobicity allows the organic chains to interact with the surface and remove water, if produced, which is an undesired product and lower the catalytic activity. On the other hand, the hydrophilic surface sites $\mathrm{C}=\mathrm{O}$ or even $-\mathrm{SO}_{3} \mathrm{H}$ in the case of sulfonated biochars can accelerate the transesterification reaction [11].

\subsubsection{Acid Biochars Catalysts}

The first category of the research efforts in transesterification/esterification reactions for biodiesel production concerns the acid-treated biochars. This category has gained much attention and produced valuable results. The sulfonation process is usually applied either using $\mathrm{H}_{2} \mathrm{SO}_{4}$ acid solutions or $\mathrm{SO}_{3}$ vapors. The result is the creation of $-\mathrm{SO}_{3} \mathrm{H}$ groups onto the biochar surface. These groups are highly important for the activity of the catalyst. They exhibit high Bronsted acidity and they are ideal for lipids with high concentration of acids like cook waste oils. The conversion achieved is usually high, as high as $95 \%$, while the yield in fatty acid methyl esters (FAME) is lower and in the best cases, about $80 \%$. Table 1 present the results for the transesterification/esterification reaction in biodiesel production.

Table 1. Use of solid biochars as catalysts for transesterification/esterification reaction in biodiesel production.

\begin{tabular}{|c|c|c|c|c|c|c|}
\hline \multirow[b]{2}{*}{ Raw Material } & \multicolumn{3}{|c|}{ Characteristics } & \multirow{2}{*}{$\begin{array}{l}\text { Reaction } \\
\text { Temp. }{ }^{\circ} \mathrm{C}\end{array}$} & \multirow{2}{*}{$\begin{array}{l}\% \text { Conversion } \\
\text { or } \% \text { Yield }\end{array}$} & \multirow[b]{2}{*}{ Reference } \\
\hline & $\mathrm{SSA}\left(\mathrm{m}^{2} / \mathrm{g}\right)$ & $\% \mathrm{~S}$ & $\begin{array}{l}-\mathrm{SO}_{3} \mathrm{H} \\
\mathrm{mmol} / \mathrm{g}\end{array}$ & & & \\
\hline Bamboo & 2.7 & & 6 & 65 & 98.4 & [35] \\
\hline Cassava peel, irul sawdust and coconut shell & & 2 & & 85 & $96.8-85.2$ & [36] \\
\hline $\begin{array}{l}\text { Char from a commercial small-scale gasification } \\
\text { plant }\end{array}$ & $337-354$ & 2.37 & & & 96 & [37] \\
\hline Coconut meal residue & $1.3-4$ & $6-14$ & & $\mathrm{BP}$ & 92.7 & [38] \\
\hline Coconut shell & 24.2 & & 0.5 & 60 & 88 & [39] \\
\hline Coconut shell char & 244 & 4.55 & & 60 & $80 \%$ & [40] \\
\hline Coffee & $992-1218$ & & $0.45-0.72$ & 60 & 71.5 & [41] \\
\hline Corn & & 7.8 & & 60 & 92 & [42] \\
\hline D-glucose & 4.13 & & 11.9 & 80 & $>95$ & [43] \\
\hline D-glucose & $4-10.67$ & & $0.12-4.23$ & & 93 & [44] \\
\hline D-glucose & 0.31 & & 2.7 & 60 & 90 & [45] \\
\hline D-glucose or C. inophyllum seed cake & $0.2-3.4$ & 2.5 & & $130-200$ & 99 & [46] \\
\hline Douglas fir & 3.51 & 2 & & 65 & 99 & [47] \\
\hline Hardwood & $2.74-14.38$ & $1.7-2.1$ & & 65 & $77-89$ & [48] \\
\hline Jatropha curcas seed cake & $1.62-2.35$ & 23 & & $45-70$ & 99.1 & [49] \\
\hline karanja seed shells & $13-16$ & & $7.5-16$ & 120 & 95.6 & [50] \\
\hline Microalgae residue & 1 & & & 80 & 98 & [51] \\
\hline $\begin{array}{c}\text { Mixture of wood waste, white wood bark, } \\
\text { and shavings }\end{array}$ & $2-1411$ & $1.2-2.69$ & & 65 & $7.6-18.9$ & [52] \\
\hline Oat hull. & $5-49.3$ & $3-7.5$ & & $100-140$ & $27-72$ & [53] \\
\hline Oil cake waste & $8-777$ & $1.2-2.4$ & $0.16-2.21$ & 65 & 7 & [54] \\
\hline Oilseed cake & $\cong 0$ & & $3-3.3$ & 60 & 94 & [55] \\
\hline Palm seed cake & 483 & & 3.16 & $55-75$ & 98 & [56] \\
\hline Palm trunk and bagasse & $3-4.5$ & $2.7-2.98$ & $0.94-1.48$ & 65 & 83.2 & [57] \\
\hline Partially carbonized de-oiled canola meal & $<10$ & $0.2-4.4$ & & 65 & 93.8 & [58] \\
\hline $\begin{array}{l}\text { Peanut hulls, pine logging residues, and wood } \\
\text { chips }\end{array}$ & $0-242$ & $0.1-2.82$ & $0-0.86$ & $55-60$ & $90-100$ & [59] \\
\hline Peanut shell & $4-12$ & $0-3.25$ & & 120 & 90.2 & [60] \\
\hline Rice husk & 4 & 5.7 & & $70-110$ & 98.2 & [61] \\
\hline Rice husk & & & $0.43-2.43$ & 66 & 87 & [62] \\
\hline Rice husk & 4 & 2.25 & & 70 & 96 & [63] \\
\hline Sawdust & $2.35-33$ & $0-6.62$ & & 85 & 95.6 & [64] \\
\hline Spent coffee grounds & & & & 60 & $15.6-21.5$ & [65] \\
\hline Spent coffee grounds & & & & 60 & 73.4 & [66] \\
\hline Vegetable oil asphalt & $7.48-41.27$ & & 2.21 & $180-260$ & 89.93 & [67] \\
\hline Woody biomass & $857-990$ & 0.36 & & 150 & 48.1 & [68] \\
\hline
\end{tabular}


As it was stated before, the creation of $-\mathrm{SO}_{3} \mathrm{H}$ groups onto biochar surface are highly important for the activity of the catalyst. They exhibit high Bronsted acidity and they can give the $\mathrm{H}^{+}$ions to an ester molecule (A). The intermediate of the ester can now react with methanol and release the $\mathrm{ROH}$ alcohol at step (B). Finally, the negatively charged surface site $-\mathrm{SO}_{3}{ }^{-}$reacts with $\mathrm{H}^{+}$, the acid site regenerates and the circle is ready to occur again while the methyl ester is formed. The above mechanism can be seen in Figure 4.

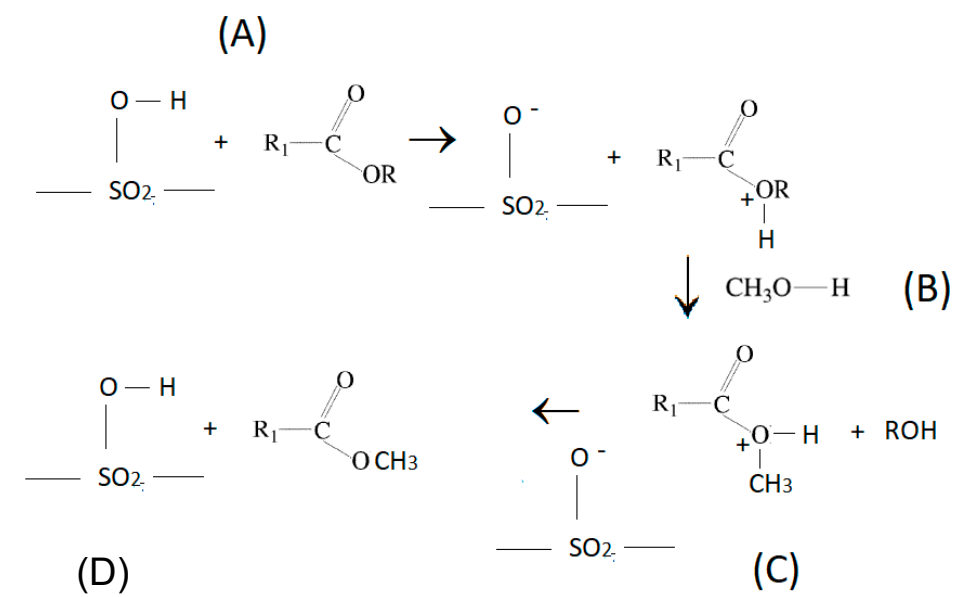

Figure 4. Transesterification reaction scheme over acid biochars catalysts, where $-\mathrm{SO}_{3} \mathrm{H}$ is a surface acid site.

Generally, the activity of the catalyst is strongly dependent on the acid site's population $[35,44,69]$. It has been reported in the literature that a large specific surface area and high acid density led to a high biodiesel production yield, whereas high transesterification activity was accompanied by a highly specific surface area when the acid density was similar. They also reported that the FFA conversion increased with increasing alcohol to oil ratio, reaction duration, and catalyst dose.

As can be seen from Table 1, the acid-modified biochars exhibit significant differences in their physicochemical characteristics. Specifically, there is great scattering in the values of the Specific Surface Area (SSA) of the produced biochars, while the differences in activity are not so significant. The reason is that the active sites are the surface $-\mathrm{SO}_{3} \mathrm{H}$ sites, which have high Bronsted acidity. Also the reaction temperature is usually the boiling point of the mixture, because of the simplicity of the experimental setup. Higher temperatures result in higher operational pressures and more complicated systems.

The physicochemical characteristics of the prepared biochar like pore size distribution, surface area, ash content, surface groups and the structure of the carbon framework is not only dependent on the preparation conditions, like temperature and oxygen content in the pyrolysis step, but also on the raw biomass materials. However, all of the above physicochemical characteristics are important for the catalyst's performance and it is not clear how the different raw materials affect the catalytic activity. It was stated in the literature that the compact graphitic phase is not active for transesterification, probably due to the absence of surface functional groups pointing out the importance of the surface active groups [70]. On the other hand, the measured activities are strongly dependent on the reaction conditions, like time, methanol to oil ratio, amount of catalyst used etc., as it was analyzed before.

\subsubsection{Basic Biochars Catalysts}

The basic character of the catalyst is important for transesterification. The basic sites of the catalysts, like $\mathrm{O}^{2-}$, can activate methanol and produce $\mathrm{CH}_{3} \mathrm{O}^{-}$ion by capturing the $\mathrm{H}^{+}(\mathrm{A})$. The methoxide produced is a very strong base and has high activity in transesterification reactions. It can react with the carbonyl carbon atom of the ester molecule or triglyceride to form a tetrahedral intermediate (B). This intermediate complex picks up the $\mathrm{H}^{+}$ion either from the protonated basic 
site or from a new methanol molecule. Then a fatty ester was released in the solution (C) and the mechanism cycle is ready to repeat until the formation of biodiesel and glycerol [71].

The above mechanism, presented in Figure 5, is similar to the one for the homogenous basic reaction and shows how important the basic sites of the catalyst are. This is the reason that basic catalysts gain attention. Usually the basic sites are oxidic sites of $\mathrm{Ca}, \mathrm{K}$ or $\mathrm{Na}$. These sites are generated at the calcination step in the case of raw materials with high content in minerals or they can be introduced onto the catalyst surface with impregnation of a precursor with $\mathrm{Ca}, \mathrm{Na}$ or $\mathrm{K}$. Usually the active phase is in the form of oxides, hydroxides or carbonates due to water and $\mathrm{CO}_{2}$ content in the atmosphere.

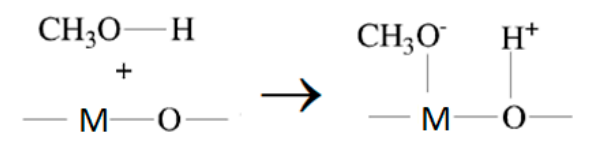

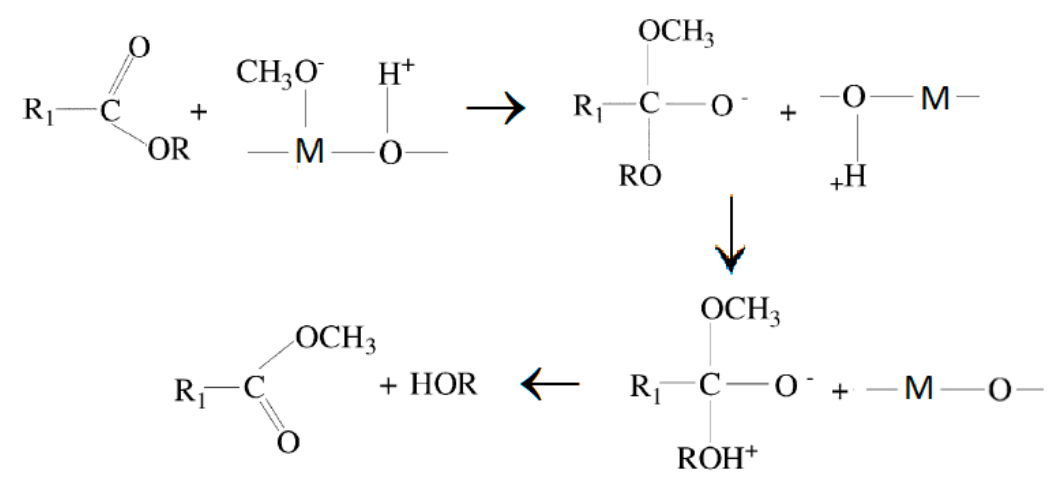

Figure 5. Transesterification reaction scheme over basic solids catalysts, where $\mathrm{M}-\mathrm{O}$ is a surface basic site created between the metal cation $(\mathrm{M})$ and the $\mathrm{O}$ atom. $(\mathrm{A}-\mathrm{C})$ the steps of reaction see text.

Biomass rich in $\mathrm{Ca}$, like bones or shells, are excellent sources for the production of solid basic catalysts for transesterification [72]. Heating in high temperature the above raw materials results in the formation of $\mathrm{CaO}$ or $\mathrm{CaCO}_{3}$. The absence of the carbon phase in the produced catalysts is the reason that it will not be analyzed further. More details about these catalysts can be found in a recent review and in references therein [31].

The stability of the above catalysts is significant. In most cases, the authors have found that the catalysts maintain their activity after recycling 3-5 times, but there are also studies that have shown that there is significant leaching of the active phase, resulting in lower activity. The stability of the catalysts is closely related with the feedstock used for transesterification. Feedstock with high acidity deactivates the catalysts used to a higher degree, increasing the leaching.

Table 2 presents the results for the transesterification/esterification reaction in biodiesel production when basic biochars have been used. As it can be seen, the usage of base biochars is limited and usually applied in triglycerides without significant acidity in contrast with the acid modified biochars. On the other hand, they exhibit significant activity and high yield to biodiesel.

Table 2. Use of base solid biochars as catalysts for transesterification/esterification reaction in biodiesel production.

\begin{tabular}{cccccc}
\hline Raw Material & Active Phase & SSA $\left(\mathbf{m}^{2} / \mathbf{g}\right)$ & $\begin{array}{c}\text { Reaction } \\
\text { Tempe. }\left({ }^{\circ} \mathbf{C}\right)\end{array}$ & $\begin{array}{c}\% \text { Conversion } \\
\text { or \% Yield }\end{array}$ & Reference \\
\hline Meat and bone meal & $\mathrm{K}_{2} \mathrm{CO}_{3}$ & $45-430$ & 65 & 98 & {$[73]$} \\
Palm kernel shells & $\mathrm{CaO}$ & - & $45-65$ & 99 & {$[74]$} \\
Peat & $\mathrm{K}_{2} \mathrm{CO}_{3}$ & $14-25$ & 65 & 98.6 & {$[75]$} \\
Peat & $20-40 \% \mathrm{wt} \mathrm{K}_{2} \mathrm{CO}_{3}$ & $80-230$ & 65 & 98 & {$[76]$} \\
Rice husk & $\mathrm{CaO}$ & $20-342$ & 65 & 98 & {$[77]$} \\
Waste pomelo peel & $15-35 \% \mathrm{wt} \mathrm{K} \mathrm{CO}_{3}$ & $3-31$ & 65 & 98 & {$[78]$} \\
\hline
\end{tabular}




\subsubsection{Pseudo Catalytic Transesterification}

Base catalyzed transesterification is the most common method, as it has been analyzed before. This method is applied either in expensive vegetable oil or when the free fatty acids are less than $0.5 \%$. Waste cooking oils, a rather cheaper feedstock, cannot be used directly because the high fatty acid concentration will reduce the biodiesel yield and make the separation process more complicated. In this case, either pretreatment or acid-catalyzed transesterification can be applied.

However, acid-catalyzed transesterification has a lower yield (about 82\%) [79].

Alternately, supercritical transesterification [80] is an improved method of acid-catalyzed reaction as it could generate $100 \%$ yield under supercritical operating conditions at $350{ }^{\circ} \mathrm{C}$ and $19 \mathrm{MPa}$ [81], see also Table 3. The reaction is fast and conversion raises $50-95 \%$ for the first $10 \mathrm{~min}$; however, it requires a temperature range of $250-400{ }^{\circ} \mathrm{C}$. The molar ratio between alcohol and lipids is 1:6-1:40. The presence of water does not affect the conversion of oil into biodiesel $[82,83]$. A certain amount of water can help the reaction because it can increase the esterification of free fatty acids.

In this method, it is not necessary the presence of a catalyst but rather a catalytically inert material like silica or biochar. The reactants are converted to biodiesel due to intense conditions and transesterification occurs inside the mesopores of the solid. The main advantage of this method is the extremely short reaction time required, which can be even as short as $1 \mathrm{~min}$ [84].

In conclusion, it can be stated that supercritical transesterification can improve biodiesel formation because it increases phase solubility; decreases mass transfer limitations; and provides higher reaction rates, easier separation, and purification.

On the other hand, mesoporous silica is a rather expensive material and biochars can replace silica due to their lower cost Also, the method is not appropriate for unsaturated fatty acids. These can decompose due to high temperature because methyl esters of unsaturated fatty acids are less thermally stable than saturated esters [85].

In a recent study, three continuous biodiesel processes were simulated with HYSYS, (HYprotech SYStem) a chemical process simulator [86]. The process includes a conventional base catalyzed process using both fresh and waste vegetable oil and a supercritical methanol process using waste vegetable. It was found that the base catalyzed process using fresh vegetable oil had the lowest total capital investment, but the supercritical process was the most economically feasible overall, providing a lower manufacturing cost, higher net present value and a discounted cash flow rate of return.

Table 3. Pseudo-catalytic transesterification/esterification with maze residue biochar and silica as an inert porous material.

\begin{tabular}{cccc}
\hline Raw Material & \% Conversion or \% Yield & Comment & Reference \\
\hline Maize residue & 95.4 & $380{ }^{\circ} \mathrm{C}$ and molar ratio of DMC to olive oil (36:1) & {$[81]$} \\
Maize residue & 87 & $380^{\circ} \mathrm{C}$ & {$[87]$} \\
Maize residue & 90.9 & $300^{\circ} \mathrm{C}$ & {$[88]$} \\
Charcoal-activate & 95 & thermally induced transesterification & {$[32]$} \\
aloumina silica & 95 & $380^{\circ} \mathrm{C}$ & {$[89]$} \\
Silica & 96.1 & $380^{\circ} \mathrm{C}$ & {$[90]$} \\
Silica & & &
\end{tabular}

\section{Conclusions}

The following conclusions can be drawn:

Biochars can be used as solid catalysts in transesterification reaction for producing biodiesel. The biochars exhibit high activity and low cost. They have a significant amount of active sites on their surface, which is easy to modify with acid or base treatment. Using acidic solution, biochars with high Bronsted acidity are produced due to surface $-\mathrm{SO}_{3} \mathrm{H}$ groups. These biochars are excellent for lipids with high acid content. On the other hand, base-modified biochars have good catalytic performance in transesterification, although their stability is not significant due to leaching problems, especially when lipids have a high acid content. 
Funding: This research received no external funding.

Conflicts of Interest: The author declares no conflict of interest.

\section{References}

1. Liew, W.H.; Hassim, M.H.; Ng, D.K.S. Review of evolution, technology and sustainability assessments of biofuel production. J. Clean. Prod. 2014, 71, 11-29. [CrossRef]

2. Liu, W.J.; Jiang, H.; Yu, H.Q. Development of Biochar-Based Functional Materials: Toward a Sustainable Platform Carbon Material. Chem. Rev. 2015, 115, 12251-12285. [CrossRef] [PubMed]

3. Kordulis, C.; Bourikas, K.; Gousi, M.; Kordouli, E.; Lycourghiotis, A. Development of nickel based catalysts for the transformation of natural triglycerides and related compounds into green diesel: A critical review. Appl. Catal. B Environ. 2016, 181, 156-196. [CrossRef]

4. Kordouli, E.; Pawelec, B.; Bourikas, K.; Kordulis, C.; Fierro, J.L.G.; Lycourghiotis, A. Mo promoted Ni-Al $\mathrm{O}_{3}$ co-precipitated catalysts for green diesel production. Appl. Catal. B Environ. 2018, 229, 139-154. [CrossRef]

5. Kordouli, E.; Sygellou, L.; Kordulis, C.; Bourikas, K.; Lycourghiotis, A. Probing the synergistic ratio of the $\mathrm{NiMo} / \gamma-\mathrm{Al}_{2} \mathrm{O}_{3}$ reduced catalysts for the transformation of natural triglycerides into green diesel. Appl. Catal. $B$ Environ. 2017, 209, 12-22. [CrossRef]

6. Kordouli, E.; Kordulis, C.; Lycourghiotis, A.; Cole, R.; Vasudevan, P.T.; Pawelec, B.; Fierro, J.L.G. HDO activity of carbon-supported Rh, Ni and MoNi catalysts. Mol. Catal. 2017, 441, 209-220. [CrossRef]

7. Kordouli, E.; Pawelec, B.; Kordulis, C.; Lycourghiotis, A.; Fierro, J.L.G. Hydrodeoxygenation of phenol on bifunctional Ni-based catalysts: Effects of Mo promotion and support. Appl. Catal. B Environ. 2018, 238, 147-160. [CrossRef]

8. Abdullah, S.H.Y.S.; Hanapi, N.H.M.; Azida, A.; Umar, R.; Juahir, H.; Khatoon, H.; Endut, A. A review of biomass-derived heterogeneous catalyst for a sustainable biodiesel production. Renew. Sustain. Energy Rev. 2017, 70, 1040-1051. [CrossRef]

9. Tang, Z.E.; Lim, S.; Pang, Y.L.; Ong, H.C.; Lee, K.T. Synthesis of biomass as heterogeneous catalyst for application in biodiesel production: State of the art and fundamental review. Renew. Sustain. Energy Rev. 2018, 92, 235-253. [CrossRef]

10. Georgogianni, K.G.; Katsoulidis, A.K.; Pomonis, P.G.; Manos, G.; Kontominas, M.G. Transesterification of rapeseed oil for the production of biodiesel using homogeneous and heterogeneous catalysis. Fuel Process. Technol. 2009, 90, 1016-1022. [CrossRef]

11. Soltani, S.; Rashid, U.; Al-Resayes, S.I.; Nehdi, I.A. Recent progress in synthesis and surface functionalization of mesoporous acidic heterogeneous catalysts for esterification of free fatty acid feedstocks: A review. Energy Convers. Manag. 2017, 141, 183-205. [CrossRef]

12. Griffiths, M.J.; van Hille, R.P.; Harrison, S.T.L. Selection of Direct Transesterification as the Preferred Method for Assay of Fatty Acid Content of Microalgae. Lipids 2010, 45, 1053-1060. [CrossRef] [PubMed]

13. Semwal, S.; Arora, A.K.; Badoni, R.P.; Tuli, D.K. Biodiesel production using heterogeneous catalysts. Bioresour. Technol. 2011, 102, 2151-2161. [CrossRef] [PubMed]

14. Suppes, G.J.; Dasari, M.A.; Doskocil, E.J.; Mankidy, P.J.; Goff, M.J. Transesterification of soybean oil with zeolite and metal catalysts. Appl. Catal. A Gen. 2004, 257, 213-223. [CrossRef]

15. Mbaraka, I.K.; Shanks, B.H. Conversion of oils and fats using advanced mesoporous heterogeneous catalysts. J. Am. Oil Chem. Soc. 2006, 83, 79-91. [CrossRef]

16. Di Serio, M.; Tesser, M.R.; Pengmei, L.; Santacesaria, E. Heterogeneous catalysts for biodiesel production. Energy Fuels 2008, 22, 207-217. [CrossRef]

17. Boutsika, L.G.; Karapanagioti, H.K.; Manariotis, I.D. Effect of chloride and nitrate salts on $\mathrm{Hg}(\mathrm{II})$ sorption by raw and pyrolyzed malt spent rootlets. J. Chem. Technol. Biotechnol. 2017, 92, 1912-1918. [CrossRef]

18. Manariotis, I.D.; Fotopoulou, K.N.; Karapanagioti, H.K. Preparation and Characterization of Biochar Sorbents Produced from Malt Spent Rootlets. Ind. Eng. Chem. Res. 2015, 54, 9577-9584. [CrossRef]

19. Kemmou, L.; Frontistis, Z.; John Vakros, J.; Manariotis, I.D.; Mantzavinos, D. Degradation of antibiotic sulfamethoxazole by biochar-activated persulfate: Factors affecting the activation and degradation processes. Catal. Today 2018, 313, 128-133. [CrossRef]

20. Waqas, M.; Aburiazaiza, A.S.; Miandad, R.; Rehan, M.; Barakat, M.A.; Nizami, A.S. Development of biochar as fuel and catalyst in energy recovery technologies. J. Clean. Prod. 2018, 188, 477-488. [CrossRef] 
21. Xiong, X.; Yu, I.K.M.; Cao, L.; Tsang, D.C.W.; Zhang, S.; Ok, Y.S. A review of biochar-based catalysts for chemical synthesis, biofuel production, and pollution control. Bioresour. Technol. 2017, 246, $254-270$. [CrossRef] [PubMed]

22. Härmas, M.; Thomberg, T.; Kurig, H.; Romann, T.; Jänes, A.; Lust, E. Microporous-mesoporous carbons for energy storage synthesized by activation of carbonaceous material by zinc chloride, potassium hydroxide or mixture of them. J. Power Sources 2016, 326, 624-634. [CrossRef]

23. Iqbaldin, M.N.M.; Khudzir, I.; Azlan, M.I.M.; Zaidi, A.G.; Surani, B.; Zubri, Z. Properties of coconut shell activated carbon. J. Trop. Sci. 2013, 25, 497-503.

24. Jain, A.; Balasubramanian, R.; Srinivasan, M.P. Production of high surface area mesoporous activated carbons from waste biomass using hydrogen peroxide-mediated hydrothermal treatment for adsorption applications. Chem. Eng. J. 2015, 273, 622-629. [CrossRef]

25. Bourikas, K.; Vakros, J.; Kordulis, C.; Lycourghiotis, A. Potentiometric mass titrations: Experimental and theoretical establishment of a new technique for determining the point of zero charge (PZC) of metal (hydr)oxides. J. Phys. Chem. 2003, 107, 9441-9451. [CrossRef]

26. Lloyd, T.A.; Wyman, C.E. Combined sugar yields for dilute sulfuric acid pretreatment of corn stover followed by enzymatic hydrolysis of the remaining solids. Bioresour. Technol. 2005, 96, 1967-1977. [CrossRef] [PubMed]

27. Wang, J.; Kaskel, S. KOH activation of carbon-based materials for energy storage. J. Mater. Chem. 2012, 22, 23710-23725. [CrossRef]

28. Gratuito, M.K.B.; Panyathanmaporn, T.; Chumnanklang, R.A.; Sirinuntawittaya, N.; Dutta, A. Production of activated carbon from coconut shell: Optimization using response surface methodology. Bioresour. Technol. 2008, 99, 4887-4895. [CrossRef] [PubMed]

29. Li, M.; Li, C.; Ca, H.; Zhao, H.; Zhang, Y.; Fan, Z. KOH self-templating synthesis of three-dimensional hierarchical porous carbon materials for high performance supercapacitors. J. Mater. Chem. A 2014, 2, 14844-14851. [CrossRef]

30. Bazargan, A.; Kostić, M.D.; Stamenković, O.S.; Veljković, V.B.; McKay, G. A calcium oxide-based catalyst derived from palm kernel shell gasification residues for biodiesel production. Fuel 2015, 150, 519-525. [CrossRef]

31. Shan, R.; Zhao, C.; Lv, P.; Yuan, H.; Yao, J. Catalytic applications of calcium rich waste materials for biodiesel: Current state and perspectives. Energy Conver. Manag. 2016, 127, 273-283. [CrossRef]

32. Jung, J.M.; Cho, J.; Kim, K.H.; Kwon, E.E. Pseudo catalytic transformation of volatile fatty acids into fatty acid methyl esters. Bioresour. Technol. 2016, 203, 26-31. [CrossRef] [PubMed]

33. Khosla, K.; Rathour, R.; Maurya, R.; Maheshwari, N.; Gnansounou, E.; Larroche, C.; Thakur, I.S. Biodiesel production from lipid of carbon dioxide sequestrating bacterium and lipase of psychrotolerant Pseudomonas sp. ISTPL3 immobilized on biochar. Bioresour. Technol. 2017, 245, 743-750. [CrossRef] [PubMed]

34. Lee, J.; Jung, J.M.; Oh, J.I.; Ok, Y.S.; Lee, S.R.; Kwon, E.E. Evaluating the effectiveness of various biochars as porous media for biodiesel synthesis via pseudo-catalytic transesterification. Bioresour. Technol. 2017, 231, 59-64. [CrossRef] [PubMed]

35. Zhou, Y.; Niu, S.; Li, J. Activity of the carbon-based heterogeneous acid catalyst derived from bamboo in esterification of oleic acid with ethanol. Energy Convers. Manang. 2016, 114, 188-196. [CrossRef]

36. Chellappan, S.; Nair, V.; Sajith, V.; Aparna, K. Experimental validation of biochar based green Bronsted acid catalysts for simultaneous esterification and transesterification in biodiesel production. Bioresour. Technol. Rep. 2018, 2, 38-44. [CrossRef]

37. Ahmad, J.; Rashid, U.; Patuzzi, F.; Baratieri, M.; Taufiq-Yap, Y.H. Synthesis of char-based acidic catalyst for methanolysis of waste cooking oil: An insight into a possible valorization pathway for the solid by-product of gasification. Energy Conver. Manag. 2018, 158, 186-192. [CrossRef]

38. Thushari, I.; Babel, S. Sustainable utilization of waste palm oil and sulfonated carbon catalyst derived from coconut meal residue for biodiesel production. Bioresour. Technol. 2018, 248, 199-203. [CrossRef] [PubMed]

39. Endut, A.; Abdullah, S.H.Y.S.; Hanapi, N.H.M.; Hamid, S.H.A.; Lananan, F.; Kamarudin, M.K.A.; Umar, R.; Juahir, H.; Khatoon, H. Optimization of biodiesel production by solid acid catalyst derived from coconut shell via response surface methodology. Int. Biodeterior. Biodegrad. 2017, 124, 250-257. [CrossRef] 
40. Hidayat, A.; Rochmadi, W.K.; Nurdiawati, A.; Kurniawan, W.; Hinode, H.; Yoshikawa, K.; Budiman, A. Esterification of Palm Fatty Acid Distillate with High Amount of Free Fatty Acids Using Coconut Shell Char Based Catalyst. Energy Procedia 2015, 75, 969-974. [CrossRef]

41. Ngaosuwan, K.; Goodwin, J.G., Jr.; Prasertdham, P. A green sulfonated carbon-based catalyst derived from coffee residue for esterification. Renew. Energy 2016, 86, 262-269. [CrossRef]

42. Liu, T.; Li, Z.; Li, W.; Shi, C.; Wang, Y. Preparation and characterization of biomass carbon-based solid acid catalyst for the esterification of oleic acid with methanol. Bioresour. Technol. 2013, 133, 618-621. [CrossRef] [PubMed]

43. Zong, M.-H.; Duan, Z.-Q.; Lou, W.-Y.; Smith, T.J.; Wu, H. Preparation of a sugar catalyst and its use for highly efficient production of biodiesel. Green Chem. 2007, 9, 434-437. [CrossRef]

44. Lokman, I.M.; Rashid, U.; Taufiq-Yap, Y.H.; Yunus, R. Methyl ester production from palm fatty acid distillate using sulfonated glucose-derived acid catalyst. Renew. Energy 2015, 81, 347-354. [CrossRef]

45. Lien, Y.-S.; Hsieh, L.-S.; Wu, J.C.S. Biodiesel Synthesis by Simultaneous Esterification and Transesterification Using Oleophilic Acid Catalyst. Ind. Eng. Chem. Res. 2010, 49, 2118-2121. [CrossRef]

46. Dawodu, F.A.; Ayodele, O.; Xin, J.; Zhang, S.; Yan, D. Effective conversion of non-edible oil with high free fatty acid into biodiesel by sulphonated carbon catalyst. Appl. Energy 2014, 114, 819-826. [CrossRef]

47. Dong, T.; Gao, D.; Miao, C.; Yu, X.; Degan, C.; Garcia-Pérez, M.; Rasco, B.; Salbani, S.S.; Chen, S. Two-step microalgal biodiesel production using acidic catalyst generated from pyrolysis-derived bio-char. Energy Convers. Manag. 2015, 105, 1389-1396. [CrossRef]

48. Dehkhoda, A.M.; West, A.H.; Ellis, N. Biochar based solid acid catalyst for biodiesel production. Appl. Catal. A Gen. 2010, 382, 197-204. [CrossRef]

49. Mardhiah, H.H.; Ong, H.C.; Masjuki, H.H.; Lim, S.; Pang, Y.L. Investigation of carbon-based solid acid catalyst from Jatropha curcas biomass in biodiesel production. Energy Convers. Manag. 2017, 144, 10-17. [CrossRef]

50. Rafi, J.M.; Rajashekar, A.; Srinivas, M.; Rao, B.V.S.K.; Prasad, R.B.N.; Lingaiah, N. Esterification of glycerol over a solid acid biochar catalyst derived from waste biomass. RSC Adv. 2015, 5, 44550-44556. [CrossRef]

51. Fu, X.; Li, D.; Chen, J.; Zhang, Y.; Huang, W.; Zhu, Y.; Yang, J.; Zhang, C. A microalgae residue based carbon solid acid catalyst for biodiesel production. Bioresour. Technol. 2013, 146, 767-770. [CrossRef] [PubMed]

52. Yu, J.T.; Dehkhoda, A.M.; Ellis, N. Development of biochar-based catalyst for transesterification of canola oil. Energy Fuels 2011, 25, 337-344. [CrossRef]

53. González, M.E.; Cea, M.; Reyes, D.; Romero-Hermoso, L.; Hidalgo, P.; Meier, S.; Benito, N.; Navia, R. Functionalization of biochar derived from lignocellulosic biomass using microwave technology for catalytic application in biodiesel production. Energy Conver. Manag. 2017, 137, 165-173.

54. Konwar, L.J.; Das, R.; Thakur, A.J.; Mäki-Arvelac, E.S.P.; Narendra, K.; Mikkola, J.P.; Deka, D. Biodiesel production from acid oils using sulfonated carbon catalyst derived from oil-cake waste. J. Mol. Catal. A Chem. 2014, 388-389, 167-176. [CrossRef]

55. Santos, E.M.; Teixeira, A.P.D.C.; da Silva, F.G.; Cibaka, T.E.; Araújo, M.H.; Oliveira, W.X.C.; Medeiros, F.; Brasil, A.N.; Oliveira, L.S.; Lago, R.M. New heterogeneous catalyst for the esterification of fatty acid produced by surface aromatization/sulfonation of oilseed cake. Fuel 2015, 150, 408-414. [CrossRef]

56. Akinfalabi, S.I.; Rashid, U.; Yunus, R.; Taufiq-Yap, Y.H. Synthesis of biodiesel from palm fatty acid distillate using sulfonated palm seed cake catalyst. Renew. Energy 2017, 111, 611-619. [CrossRef]

57. Ezebor, F.; Khairuddean, M.; Abdullah, A.Z.; Boey, P.L. Esterification of oily-FFA and transesterification of high FFA waste oils using novel palm trunk and bagasse derived catalysts. Energy Convers. Manag. 2014, 88, 1143-1150. [CrossRef]

58. Rao, B.V.S.K.; Chandra Mouli, K.; Rambabu, N.; Dalai, A.K.; Prasad, R.B.N. Carbon-based solid acid catalyst from de-oiled canola meal for biodiesel production. Catal. Commun. 2011, 14, 20-26. [CrossRef]

59. Kastner, J.R.; Miller, J.; Geller, D.P.; Locklin, J.; Keith, L.H.; Johnson, T. Catalytic esterification of fatty acids using solid acid catalysts generated from biochar and activated carbon. Catal. Today 2012, 190, 122-132. [CrossRef]

60. Zeng, D.; Liu, S.; Gong, W.; Wang, G.; Qiu, J.; Chen, H. Synthesis, characterization and acid catalysis of solid acid from peanut shell. Appl. Catal. A Gen. 2014, 469, 284-289. [CrossRef]

61. Li, M.; Zheng, Y.; Chen, Y.; Zhu, X. Biodiesel production from waste cooking oil using a heterogeneous catalyst from pyrolyzed rice husk. Bioresour. Technol. 2014, 154, 345-348. [CrossRef] [PubMed] 
62. Zhang, M.; Sun, A.; Meng, Y.; Wang, L.; Jiang, H.; Li, G. Catalytic Performance of Biomass Carbon-Based Solid Acid Catalyst for Esterification of Free Fatty Acids in Waste Cooking Oil. Catal. Surv. Asia 2015, 19, 61-67. [CrossRef]

63. Li, M.; Chen, D.; Zhu, X. Preparation of solid acid catalyst from rice husk char and its catalytic performance in esterification. Chin. J. Catal. 2013, 34, 1674-1682. [CrossRef]

64. Chellappan, S.; Nair, V.; Sajith, V.; Aparna, K. Synthesis, optimization and characterization of biochar based catalyst from sawdust for simultaneous esterification and transesterification. Chin. J. Chem. Eng. 2018. [CrossRef]

65. Haile, M. Integrated volarization of spent coffee grounds to biofuels. Biofuel Res. J. 2014, 1, 65-69. [CrossRef]

66. Haile, M.; Asfaw, A.; Asfaw, N. Investigation of waste coffee ground as a potential raw material for biodiesel production. Int. J. Renew. Energy Res. 2013, 3, 854-860.

67. Shu, Q.; Zhang, Q.; Xu, G.; Nawaz, Z.; Wang, D.; Wang, J. Synthesis of biodiesel from cottonseed oil and methanol using a carbon-based solid acid catalyst. Fuel Process. Technol. 2009, 90, 1002-1008. [CrossRef]

68. Dehkhoda, A.M.; Ellis, N. Biochar-based catalyst for simultaneous reactions of esterification and transesterification. Catal. Today 2013, 207, 86-92. [CrossRef]

69. Lee, J.; Kim, K.H.; Kwon, E.E. Biochar as a Catalyst. Renew. Sustain. Energy Rev. 2017, 77, 70-79. [CrossRef]

70. Konwar, L.J.; Boro, J.; Deka, D. Review on latest developments in biodiesel production using carbon-based catalysts. Renew. Sustain. Energy Rev. 2014, 29, 546-564. [CrossRef]

71. Liu, X.; He, H.; Wang, Y.; Zhu, S.; Piao, X. Transesterification of soybean oil to biodiesel using CaO as a solid base catalyst. Fuel 2008, 87, 216-221. [CrossRef]

72. Peng, Y.-P.; Amesho, K.T.T.; Chen, C.-E.; Jhang, S.-R.; Chou, F.-C.; Lin, Y.-C. Optimization of Biodiesel Production from Waste Cooking Oil Using Waste Eggshell as a Base Catalyst under a Microwave Heating System. Catalysts 2018, 8, 81. [CrossRef]

73. Wang, S.; Yuan, H.; Wang, Y.; Shana, R. Transesterification of vegetable oil on low cost and efficient meat and bone meal biochar catalysts. Energy Convers. Manag. 2017, 150, 214-221. [CrossRef]

74. Kostić, M.D.; Bazargan, A.; Stamenković, O.S.; Veljković, V.B.; McKay, G. Optimization and kinetics of sunflower oil methanolysis catalyzed by calcium oxide-based catalyst derived from palm kernel shell biochar. Fuel 2016, 163, 304-313. [CrossRef]

75. Wang, S.; Zhao, C.; Shan, R.; Wang, Y.; Yuan, H. A novel peat biochar supported catalyst for the transesterification reaction. Energy Conver. Manag. 2017, 139, 89-96. [CrossRef]

76. Wang, S.; Shan, R.; Wang, Y.; Lu, L.; Yuan, H. Synthesis of calcium materials in biochar matrix as a highly stable catalyst for biodiesel production. Renew. Energy 2019, 130, 41-49. [CrossRef]

77. Zhao, C.; Yang, L.; Xing, S.; Luo, W.; Wang, Z.; Lv, P. Biodiesel production by a highly effective renewable catalyst from pyrolytic rice husk. J. Clean. Prod. 2018, 199, 772-780. [CrossRef]

78. Zhao, C.; Lv, P.; Yang, L.; Xing, S.; Luo, W.; Wang, Z. Biodiesel synthesis over biochar-based catalyst from biomass waste pomelo peel. Energy Conver. Manag. 2018, 160, 477-485. [CrossRef]

79. Demirbas, A. Progress and recent trends in biodiesel fuels. Energy Convers. Manag. 2019, 50, 14-34. [CrossRef]

80. Glisic, S.B.; Orlović, A.M. Review of biodiesel synthesis from waste oil under elevated pressure and temperature: Phase equilibrium, reaction kinetics, process design and techno-economic study. Renew. Sustain. Energy Rev. 2014, 31, 708-725. [CrossRef]

81. Lee, J.; Jung, J.-M.; Oh, J.-I.; Ok, Y.S.; Kwon, E.E. Establishing a green platform for biodiesel synthesis via strategic utilization of biochar and dimethyl carbonate. Bioresour. Technol. 2017, 241, 1178-1181. [CrossRef] [PubMed]

82. Kusudiana, D.; Saka, S. Kinetics of transesterification in rapeseed oil to biodiesel fuel as treated in supercritical methanol. Fuel 2001, 80, 693-698. [CrossRef]

83. Kusudiana, D.; Saka, S. Effect of water on biodiesel fuel production by supercritical methanol treatment. Bioresour. Technol. 2004, 91, 289-295. [CrossRef]

84. Abbaszaadeh, A.; Ghobadian, B.; Omidkhah, M.R.; Najafi, G. Current biodiesel production technologies: A comparative review. Energy Convser. Manag. 2012, 63, 138-148. [CrossRef]

85. Kim, J.; Jung, J.-M.; Lee, J.; Kim, K.-H.; Choi, T.O.; Kim, J.-K.; Jeon, Y.J.; Kwon, E.E. Pyrogenic transformation of Nannochloropsis oceanica into fatty acid methyl esters without oil extraction for estimating total lipid content. Bioresour. Technol. 2016, 212, 55-61. [CrossRef] [PubMed] 
86. Lee, S.; Posarac, D.; Ellis, N. Process simulation and economic analysis of biodiesel production processes using fresh and waste vegetable oil and supercritical methanol. Chem. Eng. Res. Des. 2011, 89, 2626-2642. [CrossRef]

87. Jung, J.-M.; Lee, J.; Choi, D.; Oh, J.-I.; Lee, S.-R.; Kim, J.-K.; Kwon, E.E. Biochar as porous media for thermally-induced non-catalytic transesterification to synthesize fatty acid ethyl esters from coconut oil. Energy Convers. Manag. 2017, 145, 308-313. [CrossRef]

88. Lee, J.; Jung, M.Y.; Ok, Y.S.; Kwon, E.E. Sustainable approach to biodiesel synthesis via thermally induced transesterification using biochar as surrogate porous media. Energy Convers. Manag. 2017, 151, 601-606. [CrossRef]

89. Jung, J.M.; Lee, J.; Kim, K.H.; Kwon, E.E. Pyrogenic transformation of oil-bearing biomass into biodiesel without lipid extraction. Energy Convers. Manag. 2016, 123, 317-323. [CrossRef]

90. Jung, J.M.; Lee, J.; Kim, K.H.; Lee, S.R.; Song, H.; Kwon, E.E. Biodiesel conversion via thermal assisted in-situ transesterification of bovine fat using dimethyl carbonate as an acyl acceptor. ACS Sustain. Chem. Eng. 2016, 4, 5600-5605. [CrossRef]

(C) 2018 by the author. Licensee MDPI, Basel, Switzerland. This article is an open access article distributed under the terms and conditions of the Creative Commons Attribution (CC BY) license (http:/ / creativecommons.org/licenses/by/4.0/). 